\title{
ПРОБЛЕМИ СУЧАСНОЇ СІМ'Ї ТА НЕГОТОВНІСТЬ БАТЬКІВ ДО СТАТЕВО-РОЛЬОВОЇ СОЦІАЛІЗАЦІї ДІТЕЙ
}

\footnotetext{
У статті здійснено аналіз виховного потенціалу сучасної сім'ї та виокремлено деякі проблеми, з якими сучасні батьки зіткнулися. До аналізу залучені наукові розвідки психологічної, педагогічної, соџіологічної літератури зарубіжних та вітчизняних учених з иісї проблематики.

Ключові слова: проблеми сучасної сім'ї, виховні можливості, статево-рольова сочіалізація, допомога батькам.

В статье проведен анализ воспитательного потенциала современной семьи и выделены некоторые проблемы, с которыми столкнулись современные родители. $K$ анализу привлечены научные разработки психологической. педагогической, сочиологической литературы зарубежных и отечественных ученых по данной проблеме.

Ключевые слова: проблемы современной семьи, воспитательные возможности, поло-ролевая социализация, помощь родителям.

The article analyzes the educational potential of the modern family, and highlights some of the problems faced by modern parents. The areas, which deal with the research of this process, are examined; the analysis of the definitions of gender-role socialization in the scientific literature, such as psychological, sociological and pedagogical, is given.

Key words: problems of modern families, gender-role socialization, educational opportunities, assistance to parents.
}

Соціально-політичні зміни українського суспільства на межі століть вплинули на функціонування інституту сім'ї. Економічна криза зруйнувала патріархальні підвалини, сформувала нові стосунки, які виявились у відчуженні батьків і дітей.

Переоцінка суспільних цінностей відобразилась на меті й завданнях сімейного виховання. Стали очевидними ознаки кризового стану сім'ї: втрачаються традиції спадкоємності поколінь, засвоєння й передачі від старших поколінь молодшим історичного досвіду, знань; відходять у минуле взаємини прабатьків, батьків і дітей; трансформуються сімейні цінності; зростає кількість розлучень, позашлюбного народження дітей, розповсюдились цивільні шлюби. Таким чином, сім'я перестає бути провідним середовищем виховання й соціалізації для підростаючого покоління.

Актуальність цієї проблеми підтверджується й тим, що поширюються сучасні негаразди в нашому суспільстві: зростає наркоманія, алкоголізм, злочинність. Це є наслідком виховання дітей батьками, не готовими до виконання батьківських обов'язків, оскільки вони не мають необхідних основ виховання, насамперед - духовно-моральних, загальнолюдських; безвідповідально ставляться до розвитку і виховання дитини.

Дослідженням впливу сімейного виховання на формування особистості дитини присвятили свої наукові розвідки Т. Кравченко, В. Кузь, Л. Повалій, О. Хромова та інші.

Окремі аспекти процесу соціалізації дітей в умовах сім’ї розглядались Б. Кобзарем, А. Кузьменко, Н. Лукашевичем, А. Мудриком та ін.

Проблемі формування і виховання особистості в сім'ї присвячено роботи Т. Алєксєєнко, Ю. Азарова, О. Бондаревської, М. Боришевського, М. Вовчик-Блакитної, Т. Зелінської, І. Гребенникова, А. Ізмайлова, А. Конончук, Л. Маленкової, Л. Островської, О. Пінта, В. Постового, С. Соловейчика, В. Століна, Л. Чулкової, Е. Ейдеміллер, Ю. Якубової та інші.

Проблему статево-рольової соціалізації та культури статево-рольової поведінки досліджують Т. Говорун, М. Грабовський, Д. Ісаєва, В. Каган, І. Кон, Г. Крайг, Дж. Мани, Т. Машихіна, В. Ромонова, Л. Столярчук та інші.

Зважаючи на солідний список досліджень, маємо наголосити, що соціальна ситуація в державі призвела до того, що, виховуючи дітей, батьки стикаються низкою проблем.

Meта статmi - здійснити аналіз ситуації, у якій опинилась сучасна сім'я, визначити шляхи для надання допомоги сучасним батькам.

Суспільна зайнятість батьків разом із недостатнім рівнем педагогічної підготовки значно впливають на зміну характеру взаємовідносин між дітьми і батьками, що часто провокує дитину до формування невпевненості у своїх силах, розвитку негативних форм самоутвердження в суспільстві, а також у затримках психічного і мовленнєвого розвитку, вияву девіантної поведінки.

3 огляду на це спостерігаємо, що зараз особливо гостро постає питання впливу на дітей сімейного середовища, сучасний стан суспільства, моральна і духовна криза призвели до повної зневаги людських чеснот, таких, як чесність, гідність, людяність, краса душі тощо.

Через низку причин сучасні батьки не володіють методикою виховання своїх дітей, зокрема: а) порушені зв'язки між поколіннями; б) економічна криза призводить до того, що у сім'ях народжується у більшості випадків, одна дитина, це позбавило практичного досвіду і навичок 3 догляду за молодшими у сім’ї, братами та сестрами; в) різке зниження життєвого рівня, матеріальні труднощі зумовили напруженість і підвищує конфліктність у сім’ї; г) зростає кількість дітей, які виховуються в материнських розлучених сім'ях, підростаюче покоління не має наочного прикладу 
батьківських стосунків; г) поглиблюється відчуженість, автономність у стосунках дітей і дорослих, кожен живе своїм життям; д) традиції народної педагогіки не використовуються в сучасному житті сім’і; е) суспільство приділяє недостатньо уваги проблемі батьківства; є) 3МІ негативно впливають і руйнують традиційні способи виховання у сім’ї тощо.

Наведені вище міркування переконують у тому, що необхідно допомагати сім’ї у створенні оптимальних психолого-педагогічних, соціальних та духовно-моральних умов для повноцінного виховання й соціалізації дітей, розвитку їхніх пізнавальних інтересів, фізичного удосконалення, набуття умінь, необхідних для подальшого життя в суспільстві.

3 огляду на те, що свідомість дитини формують саме батьки, а не телевізійні програми, друзі, вулиця, комп'ютерний клуб тощо, батьки повинні допомагати своїм дітям сприймати світ, навчити відрізняти добро від зла, закласти фундамент для життя; думати про майбутнє, не запізнитися, не згаяти часу - стати дітям духовними заступниками; їхній обов’язок - показувати приклад, гідний наслідування, високу моральність, чистоту. Батьки закладають фундамент поваги і пошани дітей. У сучасних сім'ях діти можуть бути безпритульними, їхнім вихованням може ніхто не займатися, усі турботи перекладають на вчителів, школу, суспільство. У Біблії зазначається: «Настав юнака у началі путі його: він не відхилиться від нього, і доки постаріє». (Притча 22:6). Батькам слід наводити приклади поваги і пошани до старших, тільки особистий приклад спонукає до вияву добра і блага. Усі побутові негаразди, прагнення до матеріальної забезпеченості, розлучення, цивільні шлюби і вільні стосунки у сім'ях зумовлюють безпритульність дітей при живих і здорових батьках. Батьки руйнують душі своїх дітей, життя, долю, майбутнє.

У сучасній сім’ї поступово зникає, втрачає значення стереотипний розподіл ролей на чоловічі й жіночі; у зв’язку з тим, що відбувається загальна демократизація статево-рольових стосунків, жінки все більше залучають до економічної, суспільно-політичної діяльності тощо [2, с. 47.].

Традиційне статево-рольове виховання в сім’ї, що наслідувалося та передавалося 3 поколінь, змінюється, натомість виникають зіткнення між традиційними і новими традиціями, правилами, механізмами соціалізації в сімейному середовищі, що потребує психологічної, соціально-педагогічної допомоги до адаптивної та більш гнучкої взаємодії між членами сім’ї.

Цікавими для нас є приклади 3 історії, які стосуються уваги до батьківства 3 боку держави, суспільства у різні часи людства.

Наприклад, у Я. Коменського в роботі «Материнська школа» педагог надає поради жінкамматерям, які повинні бути освіченими, глибоко розуміти наукову термінологію та володіти відповідною методикою, для того щоб дитина стала істотою розумною, мудрою, моральною $\mathrm{i}$ благочестивою [5, с. 207].

У Й. Песталоцці в «Пам'ятній записці про семінарії в кантоні Во» зазначено, що в гармонійній сім’ї кожне слово, сказане 3 метою виховання, передбачає навчання, а навчання $\epsilon$ водночас i вихованням. Він наголошує на тому, якою мірою відстає від сімейного шкільне виховання, як далеко любов до дітей з боку вчителя від материнської любові, як рідко педагог розуміє у своїй справі так багато, як мати у своїй, і наголошує, що батьківський дім - то школа моралі. Але для цього мати потребує у навчанні і вмінні [7, с. $2-7]$.

Педагогічні ідеї Ж.-Ж. Руссо у романі «Еміль, або про виховання» радить батькам, що не слід братися за виховання дитини, коли не вмієш вести їі, куди хочеш. «Пам'ятайте, що раніше, ніж ви насмілитеся взятися за формування людини, вам самому треба стати людиною; потрібно, щоб ви самі мали взірець, який дитина має наслідувати» [7, с. 2 - 7].

У своїх працях К. Ушинський указує на шляхи вдосконалення виховного потенціалу сім’ необхідність підвищувати загальну і педагогічну культуру батьків, навчити їх критично оцінювати особистий досвід виховання, допомогти їм усвідомити роль виховання у формуванні моральності дитини, навчити оцінювати дитину як особистість, яка володіє індивідуальними особливостями, має власні схильності й інтереси. Окрім терпіння і природної здатності, для виховання дітей, писав К. Ушинський, необхідні знання, загальна культура, наявність грамотності батьків у вихованні i розвитку дітей [1, с. 147].

П. Каптєрев указує на необхідність серйозної роботи суспільства, для того, щоб полегшити і направити батьків на правильне сімейне виховання [3, с. 242]. Дослідник надає допомогу і вчить батьків, як треба виховувати дітей й уникати труднощів у сімейному житті.

У 20-60-ті роки в Радянському Союзі пріоритетна роль у вихованні підростаючого покоління відводилася державі і їі суспільним інститутам. Відповідно всі турботи по формуванню педагогічних знань батьків було покладено на систему освіти, вчителів, громадські організації. В. Бехтєреєв, Г. Брук, А. Сфімова та ін. пропонували здійснювати виховання молоді у школі і вважали необхідним поєднати виховні можливості батьків і вчителів. Вони аналізували можливість уведення статевої просвіти в школі у процесі підготовки до сімейного життя [4].

А. Макаренко закликав організувати курси для батьків 3 основ сімейної педагогіки і стверджував, що школа повинна надавати сім’ї допомогу: «Важливо визнати, що взаємодія педагогів, психологів, медичних працівників з батьками виступає однією 3 головних можливостей реалізації виховного потенціалу сім’ї на сучасному етапі. Необхідна спеціальна література, обов’язкові курси для батьків, 
матеріальна допомога «на виховання», організація батьків за місцем проживання, постійний нагляд за життям і вихованням дітей в сім’і» [6, с. 132].

Здійснений аналіз свідчить, що в усі часи нагальною проблемою була проблема досвідченого батьківства.

Нині можна скаржитися на зайнятість й безвідповідальне ставлення батьків до своїх обов'язків, чинники недостатнього часу, але в сучасних соціальних умовах залишається дитина, яка має потребу у грамотних батьках, захисті, підтримці, взаєморозумінні, в довірливому спілкуванні.

Залишається сучасна сім'я, яка для того, щоб зберегти свою педагогічну систему виховання $і$ відновити свій статус провідної ланки у вихованні й соціалізації дітей, потребує матеріальної, соціально-педагогічної, психологічної, культурологічної допомоги.

Слід визнати, що в загальноосвітній школі накопичений педагогічний досвід освіти батьків й 3 урахуванням усіх його слабких сторін, нині багато в чому може слугувати основою для підготовки та допомоги сучасним батькам. Саме загальноосвітня школа має кваліфіковані соціально-педагогічні кадри й може надати допомогу сучасним батькам.

Побудова нової технології соціально-педагогічної підтримки батькам у розв'язанні складних питань у сімейному житті, вихованні, вимагає аналізу попереднього соціально-педагогічного досвіду роботи з означеної проблеми, переосмислення найбільш відомих моделей педагогічної освіти батьків як у вітчизняному, так і в зарубіжному досвіді, що стане темою нашого подальшого дослідження.

\section{Література}

1. Антология педагогической мысли России второй половины XIX - начала XX в. / [сост. П. А. Лебедев]. М. : Педагогика, 1990.- 608 с. 2. Віденко С. В. Психологія сексуальності та сексуальних стосунків: [навч. посіб.] / С. В. Діденко. - К. : Арістей, 2003. - 312 с. 3. Каптерев П. Ф. Избранные педагогические сочинения / П. Ф. Каптерев/ [под ред. А. М. Арсеньева]. - М. : Педагогика, 1982. - (Педагогический процесс). 4. Кравець В. П. Теорія і практика підготовки учнівської молоді до сімейного життя: дис... докт. пед. наук: 13.00.01 / В. П. Кравець. - Тернопіль, 1997. - 386 с. 5. Коменский Я. А. Избранные педагогические сочинения / Я. А. Коменский. - М. : Педагогика, 1982. - 656 с. ( В 2-х т. Т. 1). 6. Макаренко А. С. Избранные педагогические произведения // А. С. Макаренко - М. : Учпедгиз, 1955. - (О воспитании в семье). 7. Щербань П. М. Сімейне виховання вустами великих педагогів / П. М. Щербань // Освіта. - 16 - 23 липня $2003 \mathrm{p}$. 